\title{
COVID-19 Pandemi Sürecinin Kargo Sektörü Çalışanlarının İşe Yönelik Tutumlarına Etkisi: PTT Örneği
}

\author{
Derin DÖNMEZ TOPÇUOĞLU*, Emine GENÇ**
}

ÖZ

2019 yılının Aralık ayında Çin'in Wuhan eyaletinde ortaya çıkan ve daha sonra tüm dünyaya yayılan COVID-19 olarak bilinen koronavirüsle bütün dünyada sağlık, ekonomi, iş yaşamı, sosyal yaşam, tüketici davranışları gibi birçok alan etkilenmiştir. Salgın sürecinde artan e-ticaret eğilimiyle ve değişen tüketici davranışlarıyla kargo hizmeti veren kurumların iş yükü artmıştır. Bu bağlamda lojistik alanının önemli bir paydaşı olan kargo çalışanlarının pandemi sürecinden nasıl etkilendikleri bu çalışmanın ana konusunu oluşturmaktadır. Nitel ve nicel araştırma yöntemlerinin birlikte kullanıldığ çalışmada pandemi sürecinin lojistik faaliyetlere etkisi öncelikli olarak PTT kargo teslimat sayılarının karşılaştırılması ile ortaya konulmaya çalışılmıştır. Daha sonra Bartın İli Merkez ilçesinde görev yapmakta olan 22 PTT dağıtıcısı ile yarı yapılandırılmış mülakat tekniği kullanılarak görüşülmüştür. Araştırma sonucunda kargo teslimatlarında pandemi öncesi döneme oranla \%26'lık bir artış olduğu, artan iş yükünün çalışanların motivasyonunu ve iş tatminini olumsuz yönde etkilediği ortaya koyulmuştur.

Anahtar Kelimeler: COVID-19, Kargo hizmetleri, İşe yönelik tutum

JEL Sinıflandırması: D23, L87, M54

\section{The Effects of COVID-19 on Cargo Workers' Attitudes Towards Work: A Case Study of PTT}

\begin{abstract}
Many areas such as health, economy, business, social life, consumer behavior have been affected all over the world with the corona virus known as COVID-19, which emerged in Wuhan province of China in December 2019 and then spread to the whole world. With the increasing e-commerce trend and changing consumer behavior during the epidemic, the workload of the companies providing cargo services has increased. In this context, the main subject of this study is how the pandemic affects cargo employees, an important stakeholder of the logistics field. In the study, in which qualitative and quantitative research methods were used together, the effect of the pandemic on logistics activities was tried to be revealed primarily by comparing the number of PTT cargo deliveries. Later, 22 PTT delivery person working in the central district of Bartin were interviewed using a semi-structured interview technique. As a result, it was revealed that there was an increase of $26 \%$ in cargo deliveries compared to the pre-pandemic period, and the increased workload negatively affected the motivation and job satisfaction of the employees.
\end{abstract}

Keywords: COVID-19, Logistic activities, Delivery services, Attitudes towards work

JEL Classification: D23, L87, M54

Geliş Tarihi / Received: 06.02.2021 Kabul Tarihi / Accepted: 29.05.2021 Doi: 10.17541/optimum. 875531

\footnotetext{
* Bartın Üniversitesi, LEE, Bilgi ve Lojistik Yönetimi ABD, derindonmeztopcuoglu@ gmail.com, ORCID: 00000002-6366-3392

** Dr. Öğr. Üyesi, Bartın Üniversitesi, İ̈BF, Uluslararası Ticaret ve Lojistik Bölümü, egenc@bartin.edu.tr, ORCID: 0000-0003-1178-6929
} 


\section{GİRIŞ}

COVID-19 pandemi sürecinde tüketicilerin sosyal mesafe kuralına uyma zorunluluğu ve hanelerinde kalma gereklilikleri, tüketicilerde davranış değişimlerine yol açmıştır. Satın alınan ürün grubunun ne olduğu ve hangi satın alma noktasından alındığı gibi konular, değişikliklerin temelini oluşturmaktadır. Pandemide temel ihtiyaçlara talep artmış, çevrimiçi alışveriş önem kazanmıştır. Gıda, sağlık ve hijyen alanındaki ürünler ön plana çıkarken, tüketici tutumundaki değişim ise sağlıklı hayata yönelim, online alışverişe talep, dijitalleşme ve prososyal tüketim yönündedir (Çakıroğlu, Pirtini, \& Çengel, 2019: 86-96). Artan taleple ilgili çoğu kargo firması lojistik alanında verimsiz kalmıştır. Pandemi sebebiyle değişen tüketici davranışları sonucunda bazı sektörler büyürken bazı sektörler ise küçülmüştür. Bu sektörlerle ilgili yapılan araştırmalar insanların salgının getirdiği yeniliklere alışması ve değişen ihtiyaçlarını karşılamak için yeni ürün ve hizmetlere yönelmelerinin bazı tutumlarını kalıcı olarak değiştirebileceğidir (Tekin, 2020: 2344-2346). COVID-19 pandemisi dünyada ve Türkiye'de insanların tüketim alışkanlıklarını önemli derecede değişime uğratmıştır. Sürecin en önemli etkilerinden biri, toplumsal ve ticari yaşamı büyük ölçüde dijitalleşmeye doğru evriltmesidir. Dünyadaki ve Türkiye'deki e-ticarette meydana gelen büyümeyle bazı ürünlerin talebi artarken, bazı ürünlerde talep düşme eğiliminde olmuştur. Örneğin, sağlık ve kişisel bakım ürünlerine talep artmış, giyim ve aksesuar ürün gruplarına olan talep ise azalmıştır (Güven, 2020: 260-265).

Salgın tüm sektörleri olumsuz etkilerken, e-ticaret dünyasında aksine bir etki yaratmış, e-ticarette bir sıçrama yaşanmıştır. Karantina ve yasaklar, sokağa çıkmanın tehlikeli olması, fiziksel temastan kaçınma gibi sebepler fiziksel ticareti olumsuz etkilemiş̧ir. Olumsuz etkilenen fiziksel mağazalar olsa da insanların gereksinimlerinin devam etmesi kaçınılmaz bir durumdur. Koşullar değişse de insan gereksinimi farklı ölçeklerde devam etmektedir (Ticimax Blog, 2021). E-ticaretin artışıyla kargo firmalarının iş yükü artmış, kargo firmaları çoğu zaman yetersiz kalmışlardır. Tüm bu bilgiler doğrultusunda bu çalışma ile 2020 yılında ortaya çıkan yeni koronavirüs salgınının lojistik sektöründe yer alan kargo dağıtımı alanındaki etkileri tespit edilmeye ve çalışanların iş tatmin düzeylerinde değişimin olup olmadığı gözlemlenmeye çalışılmıştır.

Bu çalışma Bartın ili merkez ilçesinde görev yapmakta olan PTT dağıtıcılarının COVID19 sürecinde işe yönelik tutumlarını ve lojistik faaliyetleri açısından nasıl etkilendiklerini araştırmayı amaçlamaktadır.

\section{LITERATÜR TARAMASI}

\subsection{Lojistik Kavramı ve Lojistik Faaliyetler}

Oxford sözlüğüne göre lojistik, temelde kompleks operasyonların ayrıntılandırılmış organizasyonu ve uygulanması olarak tanımlanmaktadır. Ek olarak sözlük bu tanımı merkez alarak lojistik faaliyetlerini 'ürünlerin müşterilere ulaştırılmasını sağlayan ticari bir faaliyet' olarak belirtmektedir. Cambridge tanımına göre ise lojistik 'bir şeyin etkin düzenlenmesi, tertibi' anlamına gelmektedir (Cambridge Dictionary, 2021). 1905 yılında orduların hareketi, ihtiyaçlarının elde edilmesi, ürün ve personellerin taşınması, bakım ve yenilenmesi olarak tanımlanan lojistik kavramı, ilk kez askeri bir sözcük olarak karşımıza çıkmaktadır (Kobu, 2003: 237).

Günümüzdeyse kapsamı oldukça genişleyen lojistik kavramının çeşitli yeni tanımlamaları yapılmaktadır. Bütün dünyada 7 gün 24 saat mal ve hizmetlerin ihtiyaç duyuldukları yere, ihtiyaç duyulduğu zamanda ulaştırmakla ilgilenen lojistik, entegre edici, birleştirici bir fonksiyondur. Pazarlama, üretim, satış, finansman ve bilişim faaliyetlerini birbirine bağlayarak bu faaliyetlerin kesilmeden yürütülebilmesi için gereken operasyonların 
optimizasyonunu sağlar (Nebol, 2016: 9-10). Aynı zamanda lojistik, tedarik zinciri süresince bütün malzemelerin hareketinden sorumlu bir fonksiyondur. Tedarik zinciri bir müşteriyi tatmin etmeyi amaçlayan, birbirini izleyen olayların tümüdür. Bu olaylar nakliye, depolama ve bilgi teknolojilerini kullanarak tedarik etme, imalat, dağıtım ve atık yönetimi olarak özetlenebilir (Başkol, 2010: 48-49; Çevik ve Kaya, 2010: 23). 1960’lı yılların başından itibaren dünyada yaşanan hızlı değişimler ve bunun sonucu olarak artan rekabet, tüketicilerin ihtiyaçlarını karşılamak için, hammadde ve malzemenin, stokların, ürünlerin veya bilginin çıkış noktasından son tüketiciye kadar varana dek, etkin ve maliyetleri en aza indirmiş bir biçimde ulaşabilmesi ihtiyacını doğurmuştur (İgeme, 2005: 17). Lojistik, müşteri arzu ve gereksinimlerine uygun olarak, çıkış noktasından tüketim noktasına kadar, hammadde, yarı mamul ve mamul ve bilginin etkili ve verimli biçimde akışının ve depolanmasının sağlanmasıdır (Küçük, 2011: 27-28; Kotler \& Armstrong, 2004: 419). Tedarik Zinciri Yönetimi Profesyonelleri Konseyi'nin (CSCMP) tanımına göre lojistik, "müşterilerin ihtiyaçlarını karşılamak üzere her türlü ürün, hizmet ve bilgi akışının, hammaddenin başlangıç noktasından, ürünün tüketildiği son noktaya kadar olan tedarik zinciri içindeki hareketinin, etkin ve verimli bir şekilde akış ve depolanmasının sağlanması, kontrol altına alınması ve planlanması sürecidir". CSMCP tedarik zinciri yönetimini ise kaynakların bulunarak tedariğinin yapılması, tedariği sağlanan kaynakların ürüne dönüştürülmesi ve tüm lojistik faaliyetlerini kapsayan faaliyetlerin de planlanması ve yönetilmesini içeren bir süreç olarak tanımlamaktadır. Buna ek olarak süreçte yer alan tüm aktörlerin (tedarikçi, arac1, üçüncü parti hizmet sunanlar ve müşteriler) iş birliği ve koordinasyonunu sağlar (Nebol, 2016: 4). Tüm bu tanımlardan yararlanarak, var olan bütün lojistik uygulamaları kapsayan tanım olarak lojistik, uygarlığın varoluşuyla eş anlı olarak görülen (yalnızca imalat sektöründe değil) tüm etkinliklerin gereksinimini karşılamak amacıyla tasarlanıp icra edilen, desteklenen işlemin gereksinimlerinin belirlenmesiyle başlayıp, ürün ve hizmetlerin gereksinmelerinin giderilmesiyle sona eren işlemler bütünü olarak tanımlanabilir (Keskin, 2018: 31). Lojistik, ilk zamanlarda sadece ürün taşıma ve depolama hizmeti sağlarken, zaman geçtikçe gerekli tesislerin yerleşimiyle birlikte, ambalajlama, stok yönetimi, malzeme elleçleme, sipariş akışı, imalat planlama, istem tahmini, satın alma, satış sonrası destek, müşteri hizmetleri, tersine ve yeşil lojistik gibi faaliyetleri kapsayan genişleyen ve çeşitlenen bir kavramdır (Çakırlar, 2009: 10-12).

Lojistik faaliyetler firmanın faaliyetlerine değer katmakta, gün geçtikçe lojistik faaliyetlerin firma açısından önemi artmaktadır (Bilginer, Kayabaşı, \& Sezici, 2008: 279). Lojistik yönetimi faaliyetleri, taşıma, depolama, stok yönetimi, elleçleme, sipariş işleme, paketleme, satın alma, enformasyon yönetimini içermektedir (Gülen, 2011: 32). Lojistik faaliyetler, nakliye, depolama, paketleme, satın alma, stok yönetimi, sipariş planlama ve müşteri hizmetlerini kapsamaktadır (Dinçel \& Günbaş, 2016: 27).

Nakliye: Ham madde, yarı mamul ve mamullerin tedarik zincirinde bir sonraki kademeye geçebilmesi, o ürünün bir sonraki işlemin yapılacağı mekâna getirilmesiyle sağlanır, dolayısıyla malların bu biçimde coğrafi olarak yerinin değiştirilmesi ve konumlandırılması, taşımadır (Nebol, 2016: 13). Müşteri açısından ürünlerin değerini belirleyen etken, ürünlerin doğru zamanda ve olması gerektiği yerde olmasıdır dolayısıyla geç giden ürünler ilgili ürünün bütün değerini yok edebilmektedir, bu sebeple taşımacılık yani nakliye oldukça önemli olmakla birlikte, ürün veya hizmetin üretildiği yerden gereksinim duyulan mekâna iletilmesiyle mekân faydas1, yine ürünlerin olması gereken mekândan olması gereken zamana iletilmesiyle zaman faydası sağlanmış olmaktadır (Bakan \& Şekkeli, 2017: 25).

Depolama: Lojistik operasyonlarda, iki önemli amaç vardır, bunlardan birincisi toplam maliyetleri en aza indirmek diğeriyse müşteri memnuniyetinin artmasını sağlamaktır, bu sebeple depolamayla lojistik hedefler arasında kuvvetli bir bağ vardır (Öz, 2020: 88). Ürünlerin imalatından satışına kadar, uygun şartlar altında korunmasını sağlayan depolamanın temel hedefi 
zaman faydası sağlamak ve sunum ile istemin dengelenmesini sağlamaktır (Kayabaşı, 2010: 109)

Paketleme: Paketleme, depolama faaliyetlerinde, stok yönetiminde, taşıma planlarının yapılmasında, bakım faaliyetlerinin uygulanmasında bir başka ifadeyle bütün tedarik zinciri aşamalarında yer almaktadır (Keskin, 2015: 218). Paketleme faaliyeti son yıllarda oldukça önem kazanan bir lojistik faaliyet alanıdır. Ürünlerin çıkış noktasından tüketiciye gelinceye dek, tüm evrelerde zarar görmeden ve güvenli taşınması paketlemede en önemli amaçtır. Ayrıca çevre bilinci de dikkate alınarak, ürünlerin taşınması, korunması, reklamı gibi işlevleri yerine getirmektedir (Dinçel \& Günbaş, 2016: 31).

Satın Alma: İhtiyaç duyulan ürünlerin sağlanması olarak tanımlanan satın alma faaliyetleri, sipariş alınmasından sonra siparişin tedariğinden meydana gelmektedir. Satın alma sürecine sadece ürünün ödemesinin yapılarak sağlanması olarak bakılmamalı, süreçte aynı zamanda, kararın verilmesi, tanımlama yapılması, irtibat kurulması, tekliflerin değerlendirilmesi ve sözleşmenin yapılması gibi faaliyetleri de içerdiği göz ardı edilmemelidir (Dinçel \& Günbaş, 2016: 35). Lojistik faaliyetlerin tümünde, sağl1klı ve sürdürülebilir satın alma düzenine sahip olunmasıyla, gereksinim duyulan ürün ve malzemenin zamanında ve yeteri kadar temin edilmesi mümkündür. Bu sebeple satın alma, tedarik zincirinde başarılı olabilmek için önemli olan bir lojistik bileşenidir. Satın alma, tedarik zincirinde stok yönetimi ve depo yönetimiyle yakından ilgilidir (Keskin, 2015: 239).

Stok Yönetimi: Stok yönetimi, muhtemel müşteri ihtiyaçları yani satış tahminleri ve fiili müşteri siparişlerinden yola çıkarak, hangi ürünün ne zaman ne miktarda olması ve müşterilere sevk edilmek için stoklara alım planı, koordinesi, yürütülmesi ve kontrolünün sağlanması işlemidir. İlgili ürünler işletmenin imal ettiği malzemeler olabildiği gibi, bir başka üreticiden alınan ve satılacak olan mallar da olabilir (Nebol, 2016: 12).

Sipariş planlama: Doğru bilgi akışı, lojistik yönetiminin en önemli unsurlarındandır ve doğru bilginin aktarılmasında sipariş işleme çok önemli bir yer tutar. Bugün müşteri siparişlerinin hem daha az maliyetli hem de daha hızlı olmasındaki temel etken müşteri siparişlerinin internet bağlantısıyla alınmasıdır. Sipariş işlemlerinde çalışanların sürece egemen olmas1 ve eğitimleri önemli unsurlardır dolayısıyla önem verilmesi gerekir (Gülen, 2011: 34). Sipariş işleme, sipariş verme biçiminin belirlenmesi, sipariş iletişiminin sağlanması ve gelişmesini sağlamak, siparişin giriş faaliyetlerini yürütmek, siparişi izlemek ve son olarak siparişin tamamlanmasını gerçekleştirmek aşamalarından oluşur (Taşkın \& Emel, 2009: 25)

Müşteri Hizmetleri: İlk seferde her şeyi doğru yapmak, lojistik yönetiminde müşteri hizmetlerinin amacıdır. Müşteri, süreç, pazarlama stratejisi ve ürünlerin iyi bir biçimde tanımlanmalarıyla birlikte bütün sistemde, lojistik performans, kalite anlayışıyla birlikte artırılması amaçlanmaktadır (Tutar, Tutar, \& Yetişen, 2009: 194). Lojistiği etkileyen unsurlar; ekonomik, politik, hukuksal, kültürel ve teknolojik nedenler olarak sıralanabilir (Dinçel \& Günbaş, 2016: 39).

\subsection{Lojistik ve Kargo Hizmetleri}

TDK'deki tanıma göre, bir yerden başka bir yere taşınan yük veya posta taşıyan şirket ve bu şirketin taşıdığı posta ve yüklere kargo denir (Türk Dil Kurumu Sözlükleri, 2020). Kargo desteği ve dağıtım hizmetleri lojistik hizmet sağlayıcılarının temel hizmetlerindendir (Thai \& Grewal, 2005: 2). Diğer taşımacılık yapan nakliye işletmelerinden farklı olan kargo firmaları, farklı alanlarda imalat yapan kişi ya da kuruluşların gereksinimlerini gerekli yerlere ulaştırma hususunda yardımcı olurlar. Müşteri memnuniyeti açısından mühim olan hizmet kalitesinin belirlenmesi, geliştirilmesi, uygulanması kargo işletmeleri için önemlidir. Firmaların geleceği 
rekabetin yoğun olduğu bu alanda müşteri memnuniyetini sağlamaya bağlıdır. (Hume, 2008: 349-369) Dünyada kargo işletmesi olarak hızlı taşımacılık yapan ve benzer hizmetleri sağlayan dağıtım işletmeleri bulunmaktadır. Uluslararası Taşımacılık ve Lojistik Hizmet Üretenleri Derneği dünya kargo taşımacılığında ilk 10’u şöyle sıralamaktadır: FedEX Express, Ups Airlines, DHL Aviation, Cathay Pacific, Korean Air Cargo, Lufthansa Cargo, China Airlines, Singapore Airlines, Emirates SkyCargo, Cargolux (UTIKAD, 2012).

\subsection{Türkiye'de Kargo Hizmetleri}

Türkiye'de cumhuriyetin kuruluşuyla, taşımacılık ve haberleşme alanlarında hızlı gelişmeler yaşanmış, dünyadaki teknolojik gelişmeler ve sanayileşmedeki gelişmeler, Türkiye'ye de yansımıştır. İmalat teknolojilerinin gelişimiyle birlikte, 1950'lerden itibaren, üretimin artması, ulaşım sektörünün gelişimini de olumlu yönde etkilemiştir. 1970'lerden sonra ulaşım sektörü dikkatleri üzerine çekerek yatırımları arttırırken, kargo taşımacılığı ulaşım sektöründen sıyrılarak, kendi işleyişini oluşturmuştur (Yapraklı, 2006: 55). Türkiye'de öne çıkan kargo firmaları aşağıda Tablo 1'de gösterilmektedir.

Tablo 1: Türkiye'de Faaliyet Gösteren Kargo Firmaları Hakkında Genel Bilgi

\begin{tabular}{|c|c|c|c|c|c|c|}
\hline Firma İsimleri & $\begin{array}{l}\text { Kurul } \\
\text { uş Yılı }\end{array}$ & $\begin{array}{c}\text { Bölge } \\
\text { Müdürlüğ̈̈ }\end{array}$ & $\begin{array}{l}\text { Transfer } \\
\text { Merkezi }\end{array}$ & Araçlık Filo & $\begin{array}{c}\text { Çalışan } \\
\text { Sayısı }\end{array}$ & Şube Sayısı \\
\hline TNT KARGO & 1946 & - & - & $3000^{*}$ & $250 *$ & $43 * *$ \\
\hline DHL KARGO & 1969 & - & $18^{*}$ & $400^{*}$ & $2000^{*}$ & $57 * *$ \\
\hline ARAS KARGO & 1979 & $13 * *$ & $29 * *$ & $3320 * *$ & $12000 * *$ & $825 * *$ \\
\hline $\begin{array}{l}\text { YURT İÇ̇ } \\
\text { KARGO }\end{array}$ & 1982 & & $32 * *$ & $3910 * *$ & $13500 * *$ & $800 * *$ \\
\hline $\begin{array}{l}\text { UNITED PARSEL } \\
\text { SERVICE (UPS) }\end{array}$ & 1988 & - & - & $700 * *$ & $3000 * *$ & $260 * *$ \\
\hline $\begin{array}{l}\text { INTEL GLOBAL } \\
\text { KARGO }\end{array}$ & 1995 & $8 * *$ & - & $200 * *$ & $500 * *$ & $84 * *$ \\
\hline FILLO KARGO & 1998 & - & - & $1500 * *$ & $600 * *$ & $211 * *$ \\
\hline MNG KARGO & 2003 & $15^{* *}$ & $26 * *$ & $2200 * *$ & $8000 * *$ & $800 * *$ \\
\hline SÜRAT KARGO & 2003 & $19 * *$ & $24 * *$ & $1278 * *$ & $4000 * *$ & $556^{* *}$ \\
\hline PTT KARGO & 2008 & - & - & $10893 * *$ & $15410 * *$ & $4602 * *$ \\
\hline AGT & 2016 & - & - & - & $1100^{* *}$ & $4500 * * *$ \\
\hline
\end{tabular}

Kaynak: (Duran, 2017)'den uyarlanmıştır.

* 2017 verisi

$* * 2021$ verisi 
Türkiye'de 35-40 y1llık kısa bir geçmişe sahip olan kargo ve kurye hizmetleri, serbest piyasa ekonomisine geçişle birlikte hızla büyümüştür ve reel sektörde vazgeçilmez konumunu gün geçtikçe korumaktadır. E-ticaretin bir alt dalı olan internet mağazacılığına yapılan yatırımların büyümesiyle pazarın daha az maliyetle ürünleri arz etmesi ve yine hizmetin hızlanmasıyla, işletmeler küresel rekabette olanaklar yakalamış ve böylelikle kargo sektöründe büyük gelişmeler yaşanmıştır (Kut, 2017). Günümüzde Türkiye'de 100 binden daha fazla kişiye istihdam alanı sunan dağıtım sektörü, 25 bin araç ve 10 bin sabit merkeziyle gün geçtikçe büyümekte ve gelişmektedir ${ }^{1}$ (Kut, 2017).

Aşağıdaki tabloda ise postada çalışan istihdam düzeylerine yer verilmiştir. Türkiye'deki posta çalışanların istihdam düzeyi diğer ülkelere göre hayli düşüktür.

Tablo 2: Türkiye'deki Posta Çalışanlarının İstihdam Düzeyleri ve Bazı Ülkelerle Karşılaştırılması

\begin{tabular}{ccccc}
\hline Ülkeler & Nüfus (bin) & $\begin{array}{c}\text { Posta İd. } \\
\text { çalışan }\end{array}$ & $\begin{array}{c}\text { Sabit Merkez } \\
\text { (adet) }\end{array}$ & Gönderi adet (bin) \\
\hline ALMANYA & 82.000 & 520.000 & 13.000 & 20.887 .000 \\
\hline FRANSA & 61.000 & 273.000 & 17.000 & 20.000 .000 \\
\hline RUSYA & 143.000 & 372.000 & 41.000 & 1.222 .750 \\
\hline ITTALYA & 57.000 & 150.746 & 13.728 & 9.000 .000 \\
\hline TÜRKIYY & 80.000 & 39.000 & 4.515 & 1.000 .000 \\
\hline
\end{tabular}

Kaynak: (KARID, 2020).

\subsection{COVID-19 Pandemisi ve Etkileri}

COVID-19 pandemisiyle görünür hale gelen vahim durumlardan biri dünya üzerindeki gelişmiş devletlerin dahi bu sürece hazırlıklı olmayışıdır. Tüm ülkeler, sağlığa dair tüm plan ve programlarını bu süreçten edindikleri tecrübelerle yeniden tasarlayacaklardır. Salgın bitti diye rehavete kapılmak, tedbirlere uymamak, daha büyük felaketlere yol açabilir. Bu yüzden, tüm dünya gerek şu anki süreçte gerekse daha sonraki süreçlerde pandemilerle savaşıma uyumlu bir biçimde ve tüm insanlığın çıkarı adına hareket etmelidir (Budak \& Korkmaz, 2020: 66-75).

Pandemi sürecinde vatandaşlara getirilen dışarı çıkma yasakları, sosyal mesafe kurallarına uyma zorunlulukları tüketim davranışı değişikliklerine de neden olmuştur. Değişen tüketici davranışları bazı sektörlerin büyümesini sağlarken, bazı sektörlerin de küçülmesine neden olmuştur. Dijitalleşmeyle birlikte alışverişlerini internet üzerinden yapmaya başlayan tüketiciler pandemi süreciyle birlikte e-ticarete olan taleplerini artırmışlardır. Çoğu kargo firması

\footnotetext{
${ }^{1}$ Ülkemizde kargo ve kurye mevzuatı şu şekildedir: 4945 sayılı Karayolu Taşıma Kanunu (T.C Cumhurbaşkanlığg Mevzuat Bilgi Sistemi, 2021), Elektronik Ticarette Hizmet Sağlayıcı ve Aracı Hizmet Sağlayıcılar Hakkında Yönetmelik (T.C Cumhurbaşkanlığı Mevzuat Bilgi Sistemi, 2021) Karayolu Taşıma Yönetmeliği (T.C Cumhurbaşkanlığı Mevzuat Bilgi Sistemi, 2021), PTT'de ise kargo ve kurye hizmetleri, 6475 Sayılı Posta Hizmetleri Kanunuyla 3 Kısımdan oluşmak üzere düzenlenmiştir (Resmi Gazete, 2021).
} 
artan bu talep karşısında yetersiz kalmış, tedarik zincirinde aksaklıklar meydana gelmiştir. Yaşanan bu aksaklıklar karşısında işletmelerin çeşitli faaliyetlere önderlik ettiği, dijitalleşmeye ağırlık verildiği, çalışanların güvenlik ve sağlığına dair kontrollerin gerçekleştirildiği, kamudan alınan desteklerle ve işletmelerin kendi çabalarıyla çalışanlarının iş güvencesini sağlama almaya çalıştıkları gözlemlenmiştir (Tuna \& Çelen, 2020).

$\mathrm{Bu}$ süreçte devletlere de bazı görevler düşmektedir. Devlet tarafından istihdama yönelik tedbirler alınmalı, plan ve programlar çizilmelidir. Ayrıca bu süreçte dijitalleşmenin hızlanması için yine devlet desteği yahut eliyle internet altyapısı güçlendirilmeli ve dijitalleşmeye daha hızlı adım atılmalıdır (Balcı \& Çetin, 2019: 43). Pandemide iş sağlığ ve güvenliği tedbirlerinin değişimi ve artırılması gerekliliği ön plana çıkmıştır. Virüsün ölümcül olması, iş güvenliği önlemlerinin önemini bir kere daha kavratmış, salgınla mücadele etmek adına araç gereç alımı, işgörenlerin süreçte sıkça bilgilendirilmesi gibi işverenin sorumlulukları gündeme gelmiştir. $\mathrm{Ne}$ zaman biteceği belli olmayan bu süreçte işverenler gerekli tüm önlemleri almakla yükümlüdürler (Ateş, 2019). Sonuç olarak, pandemiyle birlikte iş hayatı değişime uğramaktadır. Bu süreci insan kaynakları birimleri çok ayrıntılı bir biçimde incelemelidir. İş hayatındaki ilerleme ve değişimleri gözlemlemeli, işletmelerin geleceği için, yaşanan duruma uygun çözümler geliştirmelidir (Öge \& Çetin, 2020).

\section{YÖNTEM}

\subsection{Araştırmanın Amacı ve Yöntemi}

Araştırmanın amacı COVID-19 pandemi sürecinin lojistik faaliyetlerine ve lojistik sektörü çalışanlarının işe yönelik tutumlarına etkisinin araştırılmasıdır. $\mathrm{Bu}$ amaç doğrultusunda lojistik faaliyetler içerisinde yer alan kargo hizmetleri araştırma kapsamında incelenmiştir. Araştırma, Bartın ili merkez ilçesinde faaliyet gösteren PTT Kargo hizmetlerini ve bu birimde görev yapmakta olan PTT dağıtıcılarını kapsamaktadır.

Türkiye genelinde 4597 adet PTT işyeri bulunmakta ve bu işyerlerinde toplam 42.307 PTT çalışanı görev yapmaktadır. Bu çalışanlardan 15410'u ise PTT Kargo biriminde dağıtıcı olarak çalışmaktadır. Türkiye genelinde faaliyette bulunan 4957 PTT iş yerinden 125 tanesi posta ve kargo iş yerleri olarak hizmet vermektedir. Bu 125 iş yerinden Bartın ili merkez ilçesinde faaliyette bulunan posta ve kargo iş yerinin seçilmesi zaman ve bütçe kısıtından kaynaklanmaktadır. Bununla birlikte seçilen il merkezi ve iş yeri ile ilgili istatistikler Türkiye geneli ile kıyaslandığında anlamlı veriler elde edilmektedir. İlk olarak Türkiye genelinde her 10000 kişiye 1,8 PTT kargo çalışanı düşmekteyken, Bartın ili merkez ilçesinde her 10000 kişiye 1,4 PTT kargo dağıtıcısı düşmektedir. İkinci olarak, Türkiye genelinde kilometrekare başına $0,019\left(15,410 / 783,562 \mathrm{~km}^{2}\right)$ PTT kargo dağıtıcısı düşmektedir. Bartın ili merkez ilçesinde de bu oran 0,019 'dur $\left(22 / 1151 \mathrm{~km}^{2}\right)$. Dolayısıyla seçilen iş yeri ile ilgili veriler (bu iş yerinde çalışanların dağıtım yaptıkları nüfusa oranları ve kilometrekare başına düşen dağıtıcısı sayısı) Türkiye ortalamasına çok yakındır. Bununla birlikte çalışmanın, sınırlılıkları dahilinde değerlendirilmesi gerekmektedir.

Gereğine uygun biçimde çeşitli sosyal süreçleri ve grupları ya da bu süreçleri deneyimleyen bireyleri inceleyerek cevaplar arayan nitel araştırma yöntemleri (Berg \& Lune, 2015: 25) ve olguları ve olayları ölçümleyebilen ve sayısal verilere dayanarak sonuçlar çıkaran nicel araştırma yöntemleri, bu çalışmada bir arada kullanılmıştır. Nicel araştırma yöntemleri kapsamında kargo hizmetlerine yönelik veriler analiz edilmiştir. Nitel araştırma yöntemleri kapsamında yarı yapılandırılmış mülakat tekniği kullanılmıştır. Görüşme yöntemiyle tecrübeler, davranışlar, fikirler, yönelimler, tepkiler ve yorumlar gibi gözlemlenemeyenleri kavramaya çalışırız (Yıldırım \& Şimşek, 2018). Yarı yapılandırılmış görüşme yönteminin seçilmesinin nedeni, bu yöntemin verileri çözümleme kolaylığı sağlaması ve görüşülen kişiye kendini 
anlatabilme imkânı sunması ve ayrıntılı bir biçimde bilgiye ulaşma avantajı sağlamasıdır. (Büyüköztürk, Kılıç Çakmak, Akgün, Karadeniz, \& Demirel, 2020: 159). Yarı yapılandırılmış görüşme formu geliştirilerek veriler toplanmıştır. Yarı yapılandırılmış mülakatla, çalışmada hem mülakat rehberi doğrultusunda sistematik bir biçimde ilerlenmesi hem de ihtiyaç halinde daha ayrıntılı bilgilere ulaşılmasına olanak sağlaması amaçlanmaktadır (Gürbüz \& Şahin, 2018: 130). Yarı yapılandırılmış mülakatın daha ayrıntılı bilgilere ulaşmasının kaynağı esneklik ve serbestliktir. Verilerin güvenilirliğini artıran unsursa yarı yapılandırılmış mülakatla daha ayrıntılı bilgilere ulaş1lmasıdır (Güçlü, 2019: 104).

\subsection{Araştırma Grubu}

Araştırma Bartın ili merkez ilçesinde faaliyet gösteren PTT Kargo Hizmetlerini ve çalışanlarını kapsamaktadır. PTT Kargo hizmetleri bünyesinde çalışanlar, 399 sayılı kanun hükmünde kararnameye (KHK) tabi çalışanlar, idari hizmet sözleşmesi (İHS) ile çalışanlar ve taşeron eliyle istihdam edilen personel olmak üzere üç farklı biçimde istihdam edilmektedir. Bu doğrultuda 2020 Aralık ayı itibariyle PTT Kargo Bartın ili merkez ilçede görev yapmakta olan 7'si 399 say1lı KHK ile, 4'ü İHS ile, 11'i de taşeron eliyle istihdam edilen toplam 22 PTT dağıtıcısı bulunmaktadır. Araştırmada tam sayım tekniği kullanılarak tüm çalışanlar ile görüşülmüştür. Katılımcıların demografik bilgilerinin dağılımı Tablo 3 'te sunulmuş̧tur.

Katılımcıların \%9,52'si kadın, \%90,48'i ise erkektir. Çalışanlarda erkeklerin oranı hayli yüksektir. Tüm çalışanların \%33,3'ü bekar, \%66,7'si evlidir. Katılımcıların yaş dağılımı üç gruba ayrılmıştır, ilk grup 26-35 yaş aralığı 15 kişiden oluşmakta ve oranı \%68,18'dir. İkinci grup 36-45 yaş aralığında 2 kişi yer almaktadır ve oranı \%9,1'dir. Üçüncü ve son grup 46-55 yaş aralığında olup, oranı $\% 22,72$ 'dir. Tüm grubun yaş ortalamas1 ise 38,68 'dir. Katılımciların yarısından fazlasını 25-35 yaş arası grup oluşturmaktadır. Bu verilerden yola çıkarak çalışanların çoğunun genç olduğu görülmektedir. Çalışanlardan 12 kişi lise mezunu olup oranı \%54,55'tir. Ön lisans mezunu 4 kişinin oranı \%18,18'dir. Lisans mezun kişi sayısı 6, oranıysa \%27,27'dir. Katılımcıların \%50'sinden fazlası lise mezunlarından oluşmaktadır. Katılımcıların hizmet yılı da üç gruba ayrılmıştır, ilk grup hizmet yılı 1-10 yıl olan 14 kişidir, oranı \%63,64'tür. İkinci grup hizmet yıl1 11-20 y1l arasında olan 3 kişinin oranı ise \%13,64, son grup olan hizmet y1l1 21-30 y11 olan 5 kişinin oranı ise \%22,72'dir. PTT'de yer alan üç kadro ayrımına göre ayrım yapıldığında ise 399'lların sayıs1 7 iken oranı 31,8, İHS'li 4 kişinin oran $1 \% 18,18$, taşeron sayıs1 ise 11 olup, oranı \%50 olmakla birlikte ağırlığı en çok olan kadrodur (Tablo 3). 
Tablo 3: Katılımcıların Demografik Dağılımları $(\mathbf{n}=22)$

\begin{tabular}{|c|c|c|c|c|c|c|c|c|c|c|c|c|}
\hline & \multicolumn{2}{|c|}{ Cinsiyet } & \multicolumn{2}{|c|}{$\begin{array}{l}\text { Medeni } \\
\text { Durum }\end{array}$} & \multicolumn{2}{|c|}{ Yaş } & \multicolumn{2}{|c|}{$\begin{array}{l}\text { Eğitim } \\
\text { Durumu }\end{array}$} & \multicolumn{2}{|c|}{ Hizmet Y1lı } & \multicolumn{2}{|c|}{ Kadro Türü } \\
\hline & $\mathbf{n}$ & $\%$ & $\mathbf{n}$ & $\%$ & $\mathbf{n}$ & $\%$ & $\mathbf{n}$ & $\%$ & $\mathbf{n}$ & $\%$ & $\mathbf{n}$ & $\%$ \\
\hline Kadın & 2 & 9,1 & - & - & - & - & - & - & - & - & - & - \\
\hline Erkek & 20 & 90,9 & - & - & - & - & - & - & - & - & - & - \\
\hline Bekar & - & - & 7 & 31,82 & - & - & - & - & - & - & - & - \\
\hline Evli & - & - & 15 & 68,18 & - & - & - & - & - & - & - & - \\
\hline 26-35 Yaş & - & - & - & - & 15 & 68,18 & - & - & - & - & - & - \\
\hline 36-45 Yaş & - & - & - & - & 2 & 9,1 & - & - & - & - & - & - \\
\hline 46-55 Yaş & - & - & - & - & 5 & 22,72 & - & - & - & - & - & - \\
\hline Lise & - & - & - & - & - & - & 12 & 54,55 & - & - & - & - \\
\hline Ön Lisans & - & - & - & - & - & - & 4 & 18,18 & - & - & - & - \\
\hline Lisans & - & - & - & - & - & - & 6 & 27,27 & - & - & - & - \\
\hline 1-10 Y1l & - & - & - & - & - & - & - & - & 14 & 63,64 & - & - \\
\hline $11-20$ Yil & - & - & - & - & - & - & - & - & 3 & 13,64 & - & - \\
\hline 21-30 Y1l & - & - & - & - & - & - & - & - & 5 & 22,72 & - & - \\
\hline $\begin{array}{l}\text { 399 Sayılı Kanun } \\
\text { Hükmünde } \\
\text { Kararname'ye göre } \\
\text { Çalışanlar }\end{array}$ & - & - & - & - & - & - & - & - & - & - & 7 & 31,82 \\
\hline $\begin{array}{l}\text { İdari Hizmet } \\
\text { Sözleşmeli }\end{array}$ & - & - & - & - & - & - & - & - & - & - & 4 & 18,18 \\
\hline Taşeron & - & - & - & - & - & - & - & - & - & - & 11 & 50 \\
\hline
\end{tabular}

\subsection{Verilerin Toplanması}

Araştırma verileri toplanmadan önce Bartın Üniversitesi Sosyal ve Beşerî Bilimler Etik Kurulundan 27.11.2020 tarih ve 220-SBB-0249 protokol numaralı karar ile etik kurul izni alınmıştır. Çalışmada kargo hizmetlerinin pandemi sürecinde nasıl etkilendiğinin belirlenmesi amacıyla Bartın PTT Merkez Müdürlüğünden COVID-19 pandemi süreci (Mart-Nisan-MayısHaziran-Temmuz-Ağustos-Eylül-Ekim-Kasım-Aralık) ve bir önceki yılın aynı aylarına yönelik kargo verileri temin edilmiştir.

Çalışanların COVID-19 pandemi sürecinin lojistik faaliyetlere ve işe yönelik tutumlarına etkisine yönelik görüşlerinin belirlenmesi amacıyla yarı yapılandırılmış mülakat tekniği kullanılarak veriler elde edilmiştir. Mülakatlarda araştırmacılar tarafindan literatür taramasına dayalı olarak hazırlanan, demografik bilgilere yönelik 6 soru ve araştırmanın amacına yönelik 8 soru olmak üzere toplam 14 sorudan oluşan yarı yapılandırılmış görüşme formu kullanılmıştır (Mülakatlarda sorulan sorular Ek:1'de tablo halinde verilmiştir). 1 Aralık-15 Aralık tarihleri 
arasında Bartın ili merkez ilçede PTT kargo hizmetlerinde görev yapan 22 çalışan ile gönüllük esasına dayalı olarak yüz yüze görüşülmüş ve araştırma verileri toplanmıştır. Veri kaybının önlenmesi hedeflenerek görüşmeler tüm katılımcıların rızası alınarak ses kaydına alınmıştır. Her bir görüşme 20-25 dakika sürmüştür.

\subsection{Verilerin Analizi}

Araştırmaya yönelik nitel ve nicel veriler toplandıktan sonra verilerin çözümlenmesi ve yorumlanmasına geçilmiştir. Nicel veriler değerlendirirken tamamlayıcı istatistiksel metotlar (frekans ve yüzde) kullanılmıştır. Verilerin dağılımı tablo ve grafik yardımıyla sunulmuştur. Yarı yapılandırılmış görüşme tekniği ile elde edilen veriler üç gruba ayrılarak içerik çözümlemesine tabi tutulmuştur. Nitel veriler dört aşamada analiz edilirler: 1-Verilerin kodlanması 2-Temaların belirlenmesi 3-Kod ve temalarda düzenleme yapılması 4- Bulguların tanım ve yorumu (Yıldırım \& Şimşek, 2018: 243). Bu çalışmada da nitel veriler çözümlenirken bu aşamalar takip edilmiştir. Nitel araştırma yönteminin gizlilik ilkesi kapsamında araştırmaya katılan hiçbir katılımcının gerçek ismi kullanılmamış, bunun yerine katılımcılar "Katılımcı 1, Katılımcı 2, ... Katılımcı 22" şeklinde kodlanmıştır. Veriler deşifre edilerek metin haline dönüştürülmüş ve deşifre edilen metinler soru gruplarına göre lojistik faaliyetlere ilişkin bulgular ve çalışanların işe yönelik tutumlarına yönelik bulgular olarak gruplandırılarak sunulmuştur.

\section{BULGULAR}

\subsection{Kargo Verilerine İlişskin Bulgular}

Bartın PTT Merkez Müdürlüğünden COVID-19 pandemi süreci (Mart-Nisan-MayısHaziran-Temmuz-Ağustos-Eylül-Ekim-Kasım-Aralık) ve bir önceki yılın aynı aylarına yönelik olarak kargo teslim verileri alınmış ve sonuçlar Tablo 2'de ve Grafik 1'de sunulmuştur.

Tablo 4: Kargo Verilerinin Dağılımı ve Değişimi

\begin{tabular}{ccccc}
\hline \multirow{2}{*}{ AYLAR } & \multicolumn{2}{c}{ Toplam Teslim Edilen Kargo } & \multicolumn{2}{c}{ 2019-2020 Yılları Arası Değişim } \\
\cline { 2 - 5 } & $\mathbf{2 0 1 9}$ YILI & $\mathbf{2 0 2 0}$ YILI & FARK & YÜZDE \\
\hline MART & 14.861 & 15.738 & 877 & $\% 5,9$ artış \\
\hline NISAN & 12.841 & 14.599 & 1.758 & $\% 13,7$ artış \\
\hline MAYIS & 13.933 & 14.492 & 559 & $\% 4$ artış \\
\hline HAZİRAN & 10.551 & 19.447 & 8.896 & $\% 84,3$ artış \\
\hline TEMMUZ & 14.183 & 19.242 & 5.059 & $\% 35,67$ artış \\
\hline ĂGUSTOS & 11.796 & 15.370 & 3.574 & $\% 30,30$ artış \\
\hline EYLÜL & 13.815 & 20.586 & 6.771 & $\% 49$ artış \\
\hline EKİ & 20.875 & 24.340 & 3.465 & $\% 16,60$ artış \\
\hline KASIM & 18.350 & 24.510 & 6.160 & $\% 33,57$ artış \\
\hline ARALIK & 24.110 & 28.599 & 4.489 & $\% 18,61$ artış \\
\hline TOPLAM & $\mathbf{1 5 5 . 3 1 5}$ & $\mathbf{1 9 6 . 9 2 3}$ & $\mathbf{4 1 . 6 0 8}$ & \%26,79 artış \\
\hline
\end{tabular}


Tablo 4 incelendiğinde COVID-19 pandemi sürecinin başladığ 2020 Mart ayından 2020 Aralık ayına kadar devam eden süreçte kargo hizmetlerinde bir önceki yılın aynı aylarına oranla \%26,79'luk bir artışın gerçekleştiği görülmektedir. Kargo hizmetlerinde en fazla artış \%84,3 oranla Haziran ayında gerçekleşmiş, bunu \%49'luk artışla Eylül ayı ve yaklaşık \% 36'lk artışla Temmuz ayı takip etmiştir.

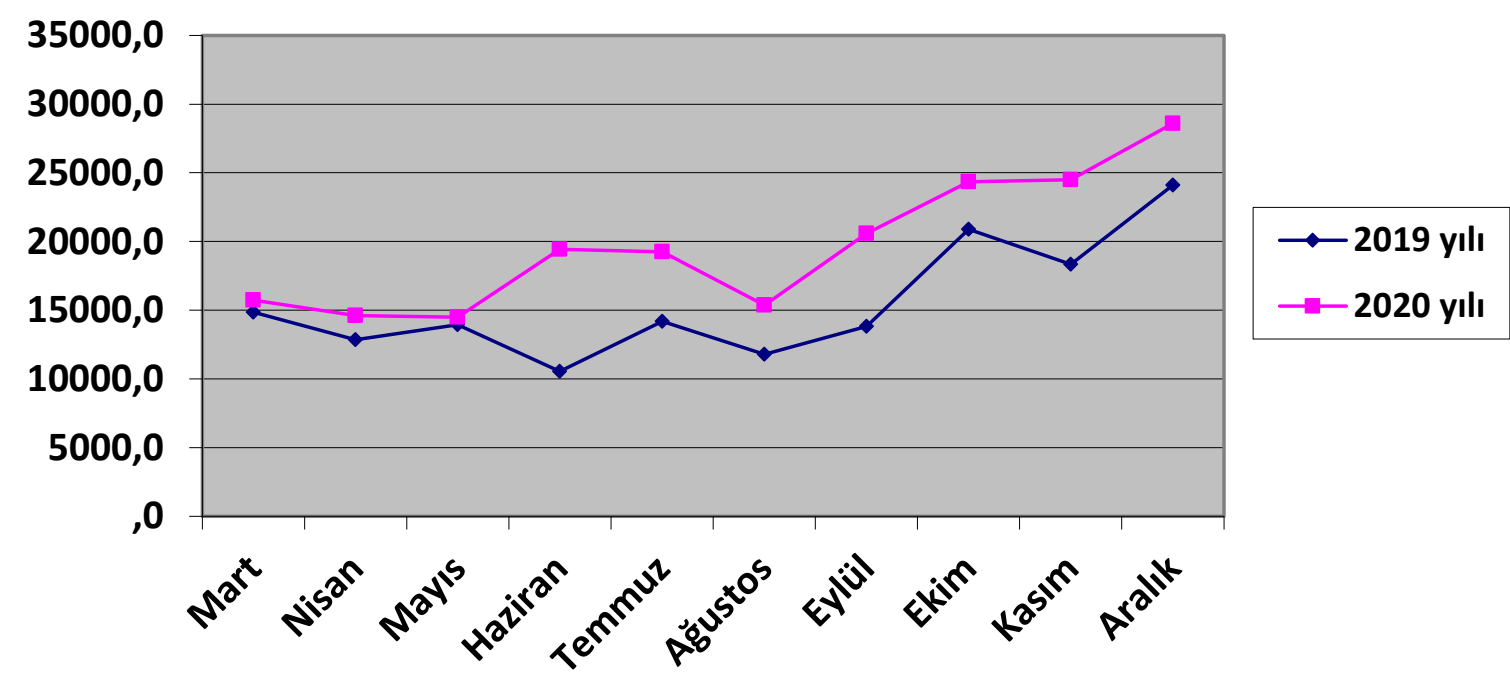

Grafik 1: Kargo Verilerinin Dağılımı

Grafik 1 incelendiğinde Bartın ili merkez ilçede pandemi sürecinde (2020 yılı MartAralık Ayları) teslimi gerçekleşen kargo sayılarında pandemi öncesi döneme göre (2019 yılı Mart-Aralık Ayları) artış olduğu görülmektedir.

\subsection{Katılımcıların COVID-19 Pandemi Sürecinin Dağıtım Faaliyetlerine Etkisine Yönelik Görüşlerine Dair Bulgular}

Lojistik faaliyetlere dair çalışanlara dört başlık altında çeşitli sorular sorulmuştur. Başlıklardan ilki tedbirlere dair soruları içermektedir. Bu kapsamda çalışanlardan 3 kişi tedbirlerin alınmadığını, 11 kişi kısmen alındığını, 8 kişi ise tedbirlerin alındığını belirtmiştir. Tedbir kapsamında maske takma ve dezenfektan kullanma gibi tedbirler alınsa da bu tedbirlerin yeterli olmadığı dile getirilmiştir. Tedbirlerin alınmadığını dile getiren kişilerin kadrosu 399'dur, 399'lu kadro diğer kadrolara göre özlük hakları bakımından daha iyi durumda olan kadrodur, bu çalışanların kadro güvencelerinden dolayı tedbirlerin alınmadığını dile getirirken daha açık oldukları söylenebilir. Kısmen alındı cevabını veren 11 kişiden 2'si 399'lu, 3'ü İHS'li 6'sı ise Taşerondur. Tedbirlerle ilgili soruya verilen cevaplarda medeni durum göz önüne alındığında ulaşılan bilgilerle anlamlı bir sonuç çıkarılamamaktadır. 7 bekardan, 4 kişi kısmen alındı, 2 kişi alındı, 1 kişi alınmadı cevabını vermiş̧tir. 15 evli çalışandan 2'si alınmadığını,7 kişi kısmen alındığını, 6 kişi ise gerekli tedbirlerin alındığını düşünmektedir. Medeni duruma göre yüzde oranları alındığında ikisinde de alınmadı en az ağırlıktaki grup, kısmen alındı cevabıysa yüzde oranlamasında en yüksek dilime sahip olan gruptur. Dolayısıyla medeni durumun verilen cevaplarda anlamlı ve fark edilebilir bir sonucu çıkmamıştır. Yaş aralığına göre değerlendirildiğinde 26-35 yaş aralığındaki 15 kişiden 8 kişi kısmen alındığını, 6 kişi alındığını, 1 kişi alınmadığını belirtmiştir. 36-45 yaş aralığındaki 2 kişi kısmen alındığını düşünmektedir. 46-55 yaş aralığı 5 kişiden 2 kişi tedbirlerin alınmadığını, 1 kişi kısmen alındığını 2 kişiyse alındığını söylemiştir. Eğitim durumuna göre değerlendirildiğindeyse, lise mezunu 12 kişiden 2 
kişi alınmadığını, 6 kişi kısmen alındığını, 4 kişi ise gerekli tedbirlerin alındığını dile getirmiştir. Ön lisans mezunu 4 kişiden 2'si kısmen alındığını, 2'si alındığını söylemiştir. Lisans mezunu 6 kişiden, 1 kişi alınmadı, 3 kişi kısmen alındı, 2 kişi alındı cevaplarını vermişlerdir. Dolayısıyla eğitim durumu ve yaş dağılımı göz önüne alındığında fark edilebilir ve anlamlı bir sonucu çıkmamıştır. Tedbirlerin alınıp alınmadığı, alındıysa yeterli olup olmadığı sorularına verilen cevaplar farklılık gösterse de bir çalışanın tedbirlere dair aksaklıkları dile getiren cevabı çok dikkat çekicidir. Tedbirlere dair aksaklıkları dile getiren Konuşmacı-6 temizlik malzemeleriyle ilgili sıkıntıyı şu şekilde aktarmıştır:' Kaç sefer pandemi çıktı kaç kişide ne ilaçlamaya gelen var ne bir şey yapmaya gelen var, ellerinizi 20 saniye yıkayacaksınız diyorlar, lavabolarda ne sabun var ne deterjan var, söyleye söyleye biz bıktı yani. Şefe söylüyoruz şef müdüre söylüyor, kendimiz alıyoruz, cebimizden alıp da burada kendimiz karşıllyoruz. Kurum deterjanı bile bize göndermiyor ya. Pandemi çıkıyor ne temizlik var ne ilaçlama var. Geçen 5, 6 kişi pozitif çıktı ne gelen var ne giden. Illaçlama yok. Bir tane temizlikçi var, o da koronalı çıktı, adam temizlik yapamıyor burada. Angarya işlerden dolayı.' Verimli bir çalışma ortamının temel koşulu, temizlik ve düzendir. Örgüt yönetimi bu konuda hassas olmalıdır. Fiziksel çalışma şartlarının iyi olması, çalışanların motivasyonunu ve verimliliğini olumlu yönde etkilemekte, iş yaşamının daha kaliteli olmasını sağlamaktadır (Gümüş \& Sezgin, 2012, s. 60). Fiziksel çalışma ortamı gözlemlendiğinde, dağıtıma çıkmadan önce ve dağıtımdan geldikten sonra evrak işlerini tamamlamak üzere günde en az iki kez çalışma masalarına oturan dağıtıcıların çok yakın mesafede işlerini yaptıkları gözlemlenmiştir. Bilgisayarlar arası mesafe 40 cm'yi geçmemektedir. Fiziksel ortamdaki göze çarpan en büyük diğer bir durum da havalandırmanın olmayışıdır. Kötü çalışma şartları motivasyonu azalttığı gibi yorgunlukla birlikte verimlilikte de düşüşe sebep olmaktadır (Hayta, 2007: 22). Tedirgin ve endişe içinde olan çalışanlar için, iş ortamının fiziksel koşullarından biri olan havalandırmanın sağlanmasıyla, çalışma şartlarının sebep olacağı olumsuzluklar ortadan kalkacaktır (Eren, 2020: 202). Durağan olmayan iş yapısı, kişilerin hareket alanını genişletirken bireyler arası mesafenin korunmamasına yol açmaktadır. Tedbir kapsamında ele alınan konularından bir diğeriyse sosyal mesafedir. Sosyal mesafeye dair önlemlerin alınmadığını dile getiren 6 kişi vardır. Sosyal mesafenin sağlanamamasına dair sorunu dile getiren kişilerden 2 kişi bekar, 4 kişi evlidir. 6 kişinin de yaş aralı̆̆ 1 26-35'tir. Eğitim durumlarına göre ise 4 kişi lisans 2 kişi ise lise mezunudur. Hizmet yıllarına bakıldığında, 3 kişi 1-10 yıl, 3 kişi ise 11-20 yıl arası görev yapmışlardır. 2 kişi 399'lu, 2 kişi İHS'li, 2 kişi ise taşeron çalışandır. Tüm bu verilerden elde edilen sonuçlarda ise, tedbirlerin alınıp alınmadığ 1 konusunda görüş birliği olmamasıdır. Bu durumdan çıkarılan sonuç PTT'nin gerekli tedbirleri almadan önce çalışanlarına danışmamış olduğudur. Çalışanların kendilerini ilgilendiren konularda fikirlerinin dinlenmesi, geleneksel yönetim anlayışının hiyerarşik yapısından sıyrılarak verimliliği artırıcı yararlar getirecektir. Yönetime katılan çalışanın da iş tatmin düzeyi artmaktadır (Eren, 2020: 411).

Başlıklardan ikincisi ise çalışanların pandemi döneminde asli görevleri (kargo, kurye ve posta) haricinde ek olarak yeni görevlerinin olup olmadığına dair soruları içermektedir. Ek işlerle ilgili soruya ilişkin cevaplar şu şekildedir: Pandeminin ilk evrelerinde 11 kişi ek iş olarak maske dağıtımı yaptığını, 3 kişi kronik hasta grubunda yer alıp o dönemi raporlu olarak atlattığını, 3 kişi maske ve maaş dağıtımına dahil olduklarını, 1 kişi maske dağıtımı ve İstanbul Halk Ekmek tarafından gönderilen ekmek dağıtımına dahil olduğunu, 4 kişi ise ek olarak yeni görevlerinin olmadığını dile getirmişlerdir. Çalışanlardan 15 kişi yeni görevler eklendiğini dile getirmiştir, \%68,18'lik bu oran yüksektir. Pandemi dolayısıyla eklenen işler iş yükünü artırmış, işe dair motivasyon düzeyini azaltmıştır. Motivasyonun amacı, çalışanların performanslarını yükseltme, kurumsal amaçlarınsa etkin ve verimli bir şekilde yerine getirilmesidir. Motivasyonu düşük olan çalışanların kapasitelerinin tamamını kullanmaması ya da kullanamaması kurumsal amaçların başarılı bir şekilde yerine getirilmemesine sebep olur (Tunçer, 2013: 93). 
Lojistik faaliyetlerine ilişkin üçüncü başlıkta çalışanlara müşterilerle ilgili sorular yöneltilmiştir. Pandemide müşterilerin bakış açısının işlerine etkisi sorulduğunda, 19 kişi etkisinin olduğunu ve bu etkilerin işlerini daha olumsuz etkilediğini düşünürken, 3 kişi ise olumlu etkilediğini düşünmektedir. Genel olarak karşılaşılan problemin müşteriler tarafindan maske takılmaması ve imza atmaktan kaçınma olduğu dile getirilmiştir. Konuşmac1-15'in aktardığı cevap şu şekildedir: 'Bir örnek vereyim size, kadın açtı kapıyı, telefonda konuşurlarken, biz pozitif çıtıtı da evdeyiz dedi. Neden kapıyı açıyorsun bana. Ki ben seninle birebir temastayım, bunu yapanlar da var. Evet şahıs karantinada ama biz onun karantinada olduğunu bilmiyoruz ki. Sürekli kendini korumak zorundasın, müşteriler buna önem vermiyorlar, çoğu kişi de gizliyor zaten. Bazen yoldan geçen biri tesadüfen kızım o binaya girme o binanın yarısı karantinada diyor, örneğin. El terminali kullandığım için T.C. kimlik numarasında hata olmuyor. Ama şimdi en azından el terminalinin avantajı var'. Pandemi sürecinde görevlendirilen yeni şefle birlikte el terminali kullanımı yaygınlaştırılmıştır, el terminaliyle birlikte müşteri kargo teslimatı sırasında dağıtıcı tarafından gönderilen tek kullanımlık teslimat koduyla ürününü teslim almakta ve hem dağıtıcı hem de müşteri açısından teslimat daha hızlı bir şekilde gerçekleştirilmektedir. Dijital sisteme entegre olan şirketler, müşterinin talep ettiği kalite ve hıza ulaşmakta ve lojistik maliyetlerini düşürmektedir (Bilgiç, Türkmenoğlu, \& Ahmet, 2020: 66). Günümüzde yaşanan teknolojik gelişmeler lojistik faaliyetleri olumlu yönde değiştirmekte, bu değişim pandemi süreciyle hız kazanmakta ve salgınla mücadelede önemli bir rol oynamaktadır. El terminali gibi küçük bir aletin bile çalışanların sağlığının korunmasında çok önemli bir rol oynadığı görülmüş̧ür. El terminalinin yaygınlaştırılmasıyla temas azaltılmakta, kâğıt israfi önlenmektedir. Çalışanın hızı artmakta, iş takibi kolaylaşmakta, dağıtıcının ofisinde geçen zaman azaltılarak verimliliği artırılmaktadır. Bununla birlikte köy dağıtımı yapan 4 kişi köylerde el terminalinin bağlantısının düşük ya da hiç olmamasından kaynaklı, el terminallerini kullanamadıklarını dile getirmişlerdir. Bu durumdan çıkarılan sonuçlarsa, PTT’nin gerekli yatırımı yapmasına rağmen yatırımın kullanılamıyor olması, bazı zamanlarda yeniliklerin kullanılamamasının sadece kurumla ilişkili olmayıp, entegre sistemlerin de eksikliğinden kaynaklanabilmekte olduğudur. Olumlu cevaplayan kişilerse, pandemi sürecinde müșterilerin bakış açısının olumsuz olmadığını dile getirmiştir. Konuşmacı-8'in ifadesi şu şekildedir: 'Pandemi sürecinde çoğu müşteri PTT'nin önemli bir kurum olduğunu anladl, çünkü özel kargonun dahi çalışmadı̆̆ diğer her şeyin durduğu vakitlerde PTT her zaman çalışt. Yani insanlar ihtiyaçlarını PTT vasitasıyla gördü. Bu süreçte bizim değerimizin daha çok arttığını düşünüyorum. Ama onun haricinde vatandaş da biz de tedirginiz, ama o şekilde yürütmeye çalıştık'. Olumlu düşünenlerin oran1 \%13,63 oranla oldukça düşük seviyededir. $\mathrm{Bu}$ durum gösteriyor ki çalışanların çoğu pandemi sürecinde müşterilerin çalışanlara bakış açısının olumsuz olduğunu düşünmektedir bu da çalışanların iş motivasyonu üzerinde oldukça olumsuz etki yaratmaktadır.

Son olarak kurumda koronavirüs vakalarının olup olmadığı eğer olduysa bu durumun işlerine nasıl yansıdığına dair sorular sorulmuştur. Kurumda pozitif vakalara rastlandığı, bunun kurum içi ilişkilerde iş yoğunluğu açısından olumsuz etki yarattığı, karantinaya alınan personeller dolayısıyla iş yükünün arttığı dile getirilmiştir. 4 kişi iş yükü artarken mesai saatinin artmadığını, 18 kişiyse iş yüküne ek olarak günde ortalama birkaç saat geç çıktıklarını söylemişlerdir. Konuşmac1-5: 'Şöyle, pandemi sürecinde, genelde eksik personelle çalıştık, o yüzden bölgemiz bir bölgeyken iki bölgeye çıktı, üç bölge oldu, bölge artışı oldu, eksik personel olunca dediğim gibi iş yükü arttı. İ̧s stresi arttı. Tabii ki herkesin bir moral bozukluğu oldu, o da tabii ki işimize yanslyor, kimsenin aslında birebir bir sorunu yokken, iş stresinden ufak tefek çatışmalar oldu'. Baskının örgütsel etkilerini, tutum, performans ve işten ayrılma olarak üç sınıfa ayırabiliriz. Baskı altında olan çalışanların tutumu işe yönelik nefret, birime ya da müşterilere karşı olumsuz duygular beslemesine sebep olabilir. Stresin az olması dahi performans1 olumsuz etkilemektedir. Bask1 altında olan çalı̧̧anlar işten ayrılmaya yönelebilmektedir. İşten ayrılma ise tamamen olabileceği gibi, işte olup işi yapmamaya dair 
yöntemler bulmak da olabilir (Aşan \& Eren Miski, 2006, s. 251). Çalışanların hepsi iş yükünün arttığını düşünmekte, \%81'lik kısım ise hem mesai hem de iş yükü artışı olduğunu dile getirmektedir. İş yükü artan çalışanların iş yoğunluğundan ve personel eksikliğinden kaynaklı sorumlu oldukları bölgeler harici, cadde, sokak ve bina numaralarını bilmedikleri başka bölgelere gitmelerinden şikâyet etmektedir. Bu durumunsa hız ve verimliliklerini olumsuz yönde etkilediğini düşünmektedirler.

\subsection{Katılımcıların COVID-19 Pandemi Sürecinin İşe Yönelik Tutumlarına Etkisine İliş̧kin Bulgular}

Çalışanların işe yönelik tutumları da dört başlık altında incelenmiştir. Başlıklardan ilki pandemi öncesi ve sonrası işe dair memnuniyet düzeylerinde olumlu ya da olumsuz değişimler yaşanıp yaşanmadığına dairdir. Çalışanların pandemi öncesi ve sonrasına dair memnuniyetlerinde olumlu ya da olumsuz bir değişim yaşanıp yaşanmadığı sorusuna verilen cevaplardan 12 kişinin pandemi sonrası işe dair memnuniyetlerinin olumsuz yönde olduğunu, 1 kişinin pandemi sonrasında memnuniyet düzeyinin daha olumlu olduğunu bunun sebebininse yaptığı işi pandemi sonrası daha önemli bulduğu çıkarılmıştır. Öte yandan 9 kişi ise memnuniyetinde herhangi bir değişim olmadığını belirtmiştir. Kadrolara göre değerlendirildiğinde, 399'lu 7 kişiden 5'i, İHS'li 4 kişiden 3'ü, Taşeron 11 kişiden 4 kişi memnuniyet düzeyinin pandemi öncesine göre daha olumsuz olduğunu belirtmişlerdir. Hizmet yılı 1-10 yıl arası olanlardan 7 kişi memnuniyet düzeyinde olumsuz yönde bir değişim yaşandığını, 6 kişi memnuniyet düzeyinde olumsuz bir değişme yaşamadığını, 1 kişi ise pandemi sonrası memnuniyet düzeyinde artış olduğunu söylemiştir. Memnuniyet düzeyinde artış olduğunu söyleyen çalışanın cevabı şu şekildedir: 'Şu an daha hevesli çallşlyorum, insanlara pandeminin en başında erzak götürüyorduk, yiyeceklerini götürüyorduk, o an kendimi önemli bir iş yapıyor olarak gördüm, pandemi öncesinde böyle bakmıyordum, pandemiden sonra bakıs açımda değişme oldu ve daha önemli bir iş yaptığımı düşünüyorum. Dağıtımın önemi, insanların bize güveni. Ben böyle düşünüyorum'. Çalışanların pandemi öncesi ve sonrasında işe dair memnuniyet düzeylerinde kadro ayrımı göz önüne alındığında anlamlı bir sonuca ulaşılamamıştır. Pandemi sürecinde çalışanların yarısından fazlasının işe dair memnuniyet düzeylerinde olumsuz bir değişim yaşanmıştır. İşlerinin olumlu ya da olumsuz etkilenmediğini söyleyenler de Türkiye'deki işsizlik problemine atıf yapmıştır. Bu durumdan, çalışanların pandemi sürecinde genel olarak olumsuz etkilendiği ama işsizlik probleminin pandemi sürecinde işe dair memnuniyetlerini derinlemesine düşünmesine engel teşkil ettiği sonucu çıkarılabilir. Çalışanların performanslarının yüksek olabilmesi ve verimli bir biçimde çalışabilmeleri için, işlerinden tatmin olmaları gerekir (Erdil, Keskin, İmamoğlu, \& Erat, 2004: 18). Kurumlar başarılarını kaybetmemek ve sürdürülebilirliklerini sağlamak istiyorlarsa, müşteriler kadar iç müşteri yani çalışanlarının da memnuniyetini sağlamalıdırlar. İç müşterinin iş tatmini arttıkça, işten ayrılmalar azalacak ve işten ayrılma sebepli ekonomik kayıplar engellenecektir. Çalıştı̆̆ kurumla duygusal bağı olan çalışanların, beklentileri hususunda algıladıkları desteğin, çalışanların kurum içerisindeki yönelim ve tutumları üzerinde büyük etkisi olacaktır. Çalışanların tutumuysa kurumdaki performansını ve başarısını etkileyecektir. Bütün bu sebeplerle, tatmin düzeyi yüksek olan çalışanlara sahip olmak, örgüt açısından çok mühimdir (Yavan, 2017).

İkinci olarak çalışanların işten ayrılma ya da sektör değiştirme yönelimlerine dair sorular sorulmuştur. Bu çerçevede çalışanlardan 6 kişi pandemiden bağımsız olarak sektör değiştirmek istediklerini söylemişlerdir, 6 kişiden 1 kişi İHS'li, 3 kişi 399'lu, 2 kişi ise taşeron kadrosunda çalışmaktadır. Hizmet yılı olarak değerlendirildiğindeyse 21-30 yıl arası görev yapmış personellerden 2 kişi işten ayrılmayı düşündügünü söylemiştir. 21-30 yıl arası görev yapmış çalışanlardan hiçbiri sektör değiştirmeyi düşünmemektedir. 11-20 y1l arası görev yapan 3 kişi 
arasından iki kişi sektör değiştirmeyi pandemiden bağımsız olarak düşündüklerini dile getirmiştir, 1-10 yıl hizmet süresi olan 14 kişiden, 4 kişi pandemiden bağımsız sektör değiştirme isteklerinin var olduğunu söylemiştir. İşten ayrılmayı hiç düşünmeyenlerse, 11 kişi olup 399'lulardan 2, İHS'lilerden 2 ve Taşeronlardansa 7 kişi işten ayrılmayı hiç düşünmediklerini dile getirmiştir. Kadro ve hizmet yılı kriterlerine göre değerlendirilen işten ayrılma isteğinde ayrımlara göre anlamlı bir sonuca ulaşılamamıştır. Çalışmamızda en göze çarpan bulgulardan biri, 11 kişinin işten ayrılmayı düşünmesi bunlardan da 6 kişinin pandemiden bağımsız olarak sektör değiştirmeyi düşünmesidir. Bu açıdan bakıldığında kurum aidiyeti oluşmamış kesim yüzde ellidir. Yaş aralıkları göz önüne alındığında hepsi 26-35 yaş grubu aralığındadır.

Üçüncü olarak, çalışanlardan pandemi döneminde yöneticilerinin liderlik tutumunu değerlendirmeleri istendiğinde, 14 kişi olumsuz, 5 kişi olumsuz olmayan 3 kişi de olumlu değerlendirmelerde bulunmuştur. Yaş aralığına göre değerlendirildiğinde, 26-35 yaş aralığı cevapları, 9 olumsuz, 4 olumsuz değil, 2 olumlu değerlendirme yapılmıştır. 36-45 yaş aralığındaki 2 kişi olumsuz değerlendirme yapmıştır. 46-55 yaş aralığındaki 5 kişi ise 1 olumsuz olmayan, 1 olumlu ve 3 olumsuz değerlendirme yapmışlardır. Yöneticilerin liderlik tutumunu olumsuz değerlendirenlerin sayısı çoğunluktadır. Kurumlarda, kurum çalışanlarının yani lider ve astların performansları, liderle astın etkileşimine bağlıdır. Her iki taraf için de etkileşim ne denli güçlü ise, kurumlar amaçlarına ulaşırken o denli başarılı olacaklardır. Çalışanların performansının kalitesi, liderlerinin performansı ile bağlantılıdır. Çalışanların lideri tarafından onaylanması ve takdir görmesi motivasyonunu pozitif yönde etkilemektedir. Aksi takdirde personel tükenmişlik hissine kapılabilmekte ve kurumun amaçları kesintiye uğrayabilmektedir (Örücü \& Şeker, 2020: 204). Dolayısıyla PTT'deki yöneticiler bu süreçte çalışanlarının yanında olduğunu hissettirerek hem çalışan motivasyonunu hem de kurumun amaçlarının gerçekleşmesini sağlayabilmek adına daha somut adımlar atmalıdır. Çalışanların yarısından fazlası kurum için, işin personelden daha mühim olduğunu hissettiğini dile getirmektedirler. Konuşmac1-15: 'İ̧̧ istemek kolay, tabii ki iş isteyecekler, ama kimse buraya gelip ne kadar zor durumda ya da ne kadar sıkıntıda olduğumuzu gelip görmüyor, dolayısıyla bilmiyorlar, kimin bölgesi daha yoğun bilmiyorlar, çünkü sahayı bilmiyorlar. Sadece sahaya çık bunu yap tamam bunu yapayım da sahadaki şartlar tamamen belirsiz şartlar. Gün geliyor sayı yükseliyor, ertesi gün düşünce neden düştü, işte sen sahayı bilmiyorsun, bilmediğin için de sadece o yapmamış olarak görüyorlar'. Konuşmac1-8: 'Yöneticileri bu süreçte pek bulamadık, pandemide çalışanın yöneticisinin arkasında olduğunu bilmesi aidiyet duygusunu kuvvetlendiriyor. Ancak bu buranın mı sorunudur, yoksa ülke genelinde midir bilmem ama çalışanın arkasında yönetici yok, bu da çalışanı yalnızlaştırıyor, aidiyet duygusunu motivasyonunu azaltıyor. Bu şartlar altında çalışmaya çalışlyoruz yani'.

Son olarak, çalışanlara kurumsal desteğin yeterliliği ile ilgili sorular sorulmuştur. Kurumun sağladığı destek 2 kişi tarafindan yeterli bulunurken, 20 kişi gerek maddi gerek manevi destek konusunda kurumu yetersiz bulduklarını belirtmişlerdir. Çalışanların \%090'1 kurumun sağladığı desteği yeterli bulmamaktadır, bu oran şu ana kadarki bulgulardan en yüksek olan orandır. Çalışana değer verme, çalışma ortamlarının iyileştirilmesi, çalışanların düşüncelerine değer verme, şikayetlerinin dinlenmesi ve önemsenmesi, başarılarının takdir edilmesi ve ödüllendirilmesi gibi kurumsal destekler kuruma dair aidiyeti artırmaktadır (Özdevecioğlu, 2016: 126). Kurumsal destek açısından çalışanlar ve üst yönetimin iletişimi üzerinde önemle durulması gerekir. Üst yönetim birbirleriyle çelişmeyen ifade, politika ve uygulamalarını örtülü ya da açı yürütürken, çalışanına değerli ve önemli olduğunu hissettiren mesaj, övgü ve onaylarla kurumsal desteği hissettirmelidir (Akın, 2008: 142). Kurumun çalışanlarının katkılarına değer vermesi, çalışanın kurum içinde benimsendiği ve istendiğine işaret olabilir. Bu işaretten yola çıarak, çalışanın işine yönelik olumlu tutumlar geliştirmesi ve sonucunda iş tatmini sağlanmasıyla çalışanın kurumuna karşı olumlu tutumlar geliştirmesine katkıda bulunarak çalışanın kurumda kalma isteği ile performans düzeyi artırılabilir (Çakar \& 
Yıldız, 2009: 77). Kurumsal desteğin, takdir ve onaylama gereksinimlerinin karşılanmasıyla, çalışanlar kurumlarına karşı duygusal bir bağ geliştirirler, bu bağla çalışanlar daha aktif ve daha başarılı hatta kurumsal amaçlara ulaşma hedeflerini artırmış olacaklardır (Altınöz, Çöp, Çakıroğlu, Kervancı, \& Keskin, 2013: 151).

\section{TARTIŞMA ve SONUÇ}

Çalışma sonucu elde edilen bulgulardan ve yapılan tartışmalardan birtakım öneriler geliştirilebilir. Tedbir konusunda fikir birliği olmamasında PTT'nin kurumsal olarak bir rolü olabileceği sonucuna varılmıştır. Çalışanın fikrinin alınmasıyla çalışanların tatmin düzeylerinin artması beklenmekte bu durumun da kurumsal hedeflerin gerçekleşmesine olumlu etkisi olacağı düşünülmektedir. Pandemi dolayısıyla eklenen işler iş yükünü artırmış, işe dair motivasyon düzeyinin azalmasına sebep olmuştur. $\mathrm{Bu}$ durumda kurum motivasyon artırıcı eylemlerde bulunmalı, iş yükü artan personelin mesai artışı ücret ya da maaşlarına yansıtılarak çalışanın mesai artışının maliyeti kurum tarafindan karşılanmalıdır. Çalışanların çoğu pandemi sürecinde müşterilerin çalışanlara bakış açısının olumsuz olduğunu düşünmektedir bu da çalışanların iş motivasyonu üzerinde oldukça olumsuz etki yaratmaktadır. Halbuki pandemi boyunca kargo çalışanlarının çalışma şartları normal zamanlara göre kat kat ağırlaşmıştır. Kargo çalışanları bu süreçte tam zamanlı çalışmışlar, sokağa çıkma yasağında dahi çalışmış, dönüşümlü çalışmaya geçmemişlerdir. Çoğu zaman öğle yemeği bile yiyememişlerdir. Müşterilerin kargo çalışanlarına karşı takındığı tutumun yarattığı olumsuz etkinin ortadan kalkması için kargo çalışanlarına dair algının değişmesi gerekmektedir. Müşterilerdeki kargo çalışanlarına yönelik olumsuz algıyı değiştirmek adına kargo çalışanlarının ne kadar zor ve önemli bir görev üstlendiklerine dair bilgilendirmeler yapılabilir ve kamu spotları yayınlanabilir ya da PTT aracılığıyla reklamlar yapılabilir. Yukarıda da görüldüğü üzere çalışanların hepsi iş yükünün arttığını düşünmekte, $\% 81$ 'lik kısım ise hem mesai hem de iş yükü artışı olduğunu dile getirmektedir. İş yükü artışının getirdiği stres ise çalışanlarda verimsizliğe yol açmaktadır. Dolayısıyla stres ortamının azaltılması için yönetici ve liderlere önemli görevler düşmektedir. Ayrıca bulgular kısmında değinildiği gibi, teknolojik gelişmelerin kullanılması kargo çalı̧̧anlarının hem işlerini kolaylaştırmakta hem de pandemi gibi hassas dönemlerde sağlıklarını korumaktadır. Lakin teknolojik gelişmelerin entegre sistemlerle bir bütünlük içerisinde işlediği unutulmamalıdır. Örneğin kargo çalışanlarının kullandığı el terminali işlerini kolaylaştırdığı gibi sağlıklarını da korumaktadır fakat alt yapı yetersizliği bu aletlerin her bölgede kullanılmasını engellemektedir. Telekomünikasyonun geliştirilmesiyle el terminali kullanımı köylerde de mümkün hale gelecek dolayısıyla verimlilik daha çok artacaktır.

Pandemi sürecinin çalışanların yarısından fazlasının işe dair memnuniyet düzeyleri üzerinde olumsuz etkisi olduğu gözlemlenmiştir. Çalışmamızda en göze çarpan bulgulardan biri, 11 kişinin işten ayrılmayı düşünmesi bunlardan da 6 kişinin pandemiden bağımsız olarak sektör değiştirmeyi düşünmesidir. $\mathrm{Bu}$ açıdan bakıldığında kurum aidiyeti oluşmamış kesim yüzde ellidir. Yaş aralıkları göz önüne alındığında hepsi 26-35 yaş grubu aralığındadır. Çalışanlar yöneticilerinin liderlik tutumunu olumsuz değerlendirmektedirler, dolayısıyla yöneticiler çalışanlarının yanında olduğunu hissettirmek için daha sık ziyaretlerde bulunmalı, sorunlarını dinlemeli ve çözüm bulmaya yönelik tutumlar geliştirmelidir. Çalışanların \%90'1 kurumun sağladığı maddi manevi desteği yeterli bulmamaktadır. Kurum hedeflerine ulaşabilmesi için öncelikle çalışanlarının motivasyon ve bağlılıklarını artıracak politikalara öncelik vermelidir.

Pandeminin lojistik faaliyetler içerisinde yer alan kargo dağıtım alanına odaklanan bu çalışma Türkiye'de benzer konularda yapılabilecek diğer çalı̧̧malara da ışı tutmaktadır. Ancak bu araştırmanın bulguları bazı sınırlamalar çerçevesinde değerlendirilmelidir. Öncelikle araştırmanın örneklemi yalnızca Bartın PTT Merkez İlçe Müdürlüğünde çalışan dağıtıcılardan oluşmaktadır. Bu nedenle bulguların genelleştirilebilirliği de bu çerçevede değerlendirilmelidir. 
Dönmez Topçuoğlu ve Genç - COVID-19 Pandemi Sürecinin Kargo Sektörü Çalışanlarının İşe Yönelik Tutumlarına Etkisi: PTT Örneği

\section{Araştırma ve Yayın Etiği Beyanı}

$\mathrm{Bu}$ çalışma bilimsel araştırma ve yayın etiği kurallarına uygun olarak hazırlanmıştır. Araştırma verileri toplanmadan önce Bartın Üniversitesi Sosyal ve Beşerî Bilimler Etik Kurulundan 27.11.2020 tarih ve 220SBB-0249 protokol numaralı karar ile etik kurul izni alınmıştır.

\section{Yazarların Makaleye Katkı Oranları}

Birinci yazarın makaleye katkısı \%50, İkinci yazarın makaleye katkısı \%50’dir.

\section{Çıkar Beyanı}

Yazarlar açısından ya da üçüncü taraflar açısından çalışmadan kaynaklı çıkar çatışması bulunmamaktadır. 


\section{KAYNAKÇA}

Akın, M. (2008). Örgütsel destek, sosyal destek ve iş/aile çatışmalarının yaşam tatmini üzerindeki etkileri, Erciyes Üniversitesi Sosyal Bilimler Enstitüsü Dergisi, 1(25), 141-171.

Altınöz, M., Çöp, S., Çakıroğlu, D., Kervancı, F., \& Keskin, N. (2013). Algılanan örgütsel desteğin büro çalışanlarının örgütsel bağlılık üzerine etkisi: bir alan araştırması, Süleyman Demirel Üniversitesi Sosyal Bilimler Enstitüsü Dergisi, (Büro Yönetimi Özel Sayıs1), 149-163.

Aşan, Ö., \& Eren Miski, A. (2006). Örgütsel davranış. 1 baskı. İstanbul: Hiperlink.

Ateş, Z. G. (2019, Yaz 2020/2 (COVID-19 Özel Ek). COVID-19'un işverenin iş sağlığı ve güvenliği konusunda alması gereken önlemlere etkisi, İstanbul Ticaret Üniversitesi Sosyal Bilimler Dergisi, COVID-19 Hukuk Özel Saylsı, 161-179.

Bakan, İ., \& Şekkeli, Z. (2017). Lojistik yönetimi. İstanbul: Beta Basım Yayım Dağıtım A.Ş.

Balcı, Y., \& Çetin, G. (2019). COVID-19 pandemi sürecinin türkiye'de istihdama etkileri ve kamu açısından alınması gereken tedbirler, İstanbul Ticaret Üniversitesi Sosyal Bilimler Dergisi, COVID-19 Sosyal Bilimler Özel Say1s1 (37), 4058 .

Başkol, M. (2010). Lojistik ve lojistik yönetimi, Bartın Üniversitesi İktisadi ve İdari Bilimler Fakültesi Dergisi, 1(2), 47-64.

Berg, B. L., \& Lune, H. (2015). Sosyal bilimlerde nitel araştırma yöntemleri. Konya: Eğitim Kitapevi.

Bilgiç, E., Türkmenoğlu, M. A., \& Ahmet, K. (2020). Dijitalleşmenin lojistik yönetimi bağlamında incelenmesi, Bitlis Eren Üniversitesi İktisadi ve İdari Bilimler Fakültesi Akademik İzdüşüm Dergisi, 1(5), 56-69.

Bilginer, N., Kayabaş1, A., \& Sezici, E. (2008, Aralık). Lojistik faaliyetlerin süreçsel etkinliğine etki eden faktörlerin değerlendirilmesi üzerine ampirik bir çalışma, Dumlupınar Üniversitesi Sosyal Bilimler Dergisi, (22), 277-295.

Budak, F., \& Korkmaz, Ş. (2020). COVID-19 pandemi sürecine yönelik genel bir değerlendirme: Türkiye örneği, Sosyal Araştırmalar ve Yönetim Dergisi (SAYOD), (1) 62-79.

Büyüköztürk, Ş., Kılıç Çakmak, E., Akgün, Ö., Karadeniz, Ş., \& Demirel, F. (2020). Eğitimde bilimsel araştırma yöntemleri. 28. bask1. Ankara: Pegem Akademi.

Cambridge Dictionary. (2021, Ocak). https://dictionary.cambridge.org/tr/s\%C3\%B6z1\%C3\%BCk/ingilizce$\mathrm{t} \% \mathrm{C} 3 \% \mathrm{BCrk} \% \mathrm{C} 3 \% \mathrm{~A} 7 \mathrm{e} /$ logistics adresinden alınd 1

Çakar, N. D., \& Yıldız, S. (2009). Örgütsel adaletin iş tatmini üzerindeki etkisi: "algılanan örgütsel destek" bir ara değişken mi?, Elektronik Sosyal Bilimler Dergisi, 8(28), 68-90.

Çakırlar, H. (2009). İşletmelerin lojistik faaliyetlerinde dış kaynak kullanımı: Trakya bölgesinde faaliyet gösteren işletmeler üzerinde bir inceleme. Yüksek Lisans Tezi, Edirne.

Çakıroğlu, K. I., Pirtini, S., \& Çengel, Ö. (2019). COVID-19 sürecinde ve post-pandemi döneminde yaşam tarzı açısından tüketici davranışlarının değişen eğilimi üzerine kavramsal bir çalışma, İstanbul Ticaret Üniversitesi Sosyal Bilimler Dergisi, COVID-19 Sosyal Bilimler Özel Sayısı (37), 81-103.

Çevik, S., \& Kaya, S. (2010, Kasım). Türkiye'nin lojistik potansiyeli ve İzmir'in lojistik faaliyetleri açısından durum (Swot) analizi, Izmir Ticaret Odası, s. 22-28.

Duran, G (2017), Kargo hizmetlerin tüketici davranışına etkisi üzerine bir uygulama, Stratejik Public Management Journal, 3(5), 109-123.

Dinçel, S., \& Günbaş, Y. (2016). Lojistik yönetimi ve girişimcilik. İstanbul: Hiperlink.

Erdil, O., Keskin, H., İmamoğlu, S. Z., \& Erat, S. (2004). Yönetim tarzı ve çalışma koşulları, arkadaşlık ortamı ve takdir edilme duygusu ile iş tatmini arasındaki ilişkiler: tekstil sektöründe bir uygulama, Doğuş Üniversitesi Dergisi, $1(5), 17-26$.

Eren, E. (2020). Örgütsel Davranışve Yönetim Psikolojisi. 17. baskı. İstanbul: Beta Basım Yayım Dağıtım Aş.

Güçlü, İ. (2019). Sosyal bilimlerde nitel araştırma yöntemleri teknik-yaklaşım-uygulama. 1. baskı. Ankara: Nobel Akademik Yayıncılık Eğitim Danışmanlık Tic. Ltd.Şti.

Gülen, K. G. (2011). Lojistik sektöründe durum analizi ve rekabetçi stratejiler. İstanbul: İstanbul Ticaret Odası.

Gümüş, S., \& Sezgin, B. (2012). Motivasyonun örgütsel bağlllı̆̆a ve performansa etkisi. İstanbul: Hiperlink Yayınları. 
Dönmez Topçuoğlu ve Genç - COVID-19 Pandemi Sürecinin Kargo Sektörü Çalışanlarının İşe Yönelik Tutumlarına Etkisi: PTT Örneği

Gürbüz, S., \& Şahin, F. (2018). Sosyal bilimlerde araştırma yöntemleri felsefe-yöntem-analiz. 5. baskı. Ankara: Seçkin Yayıncılık.

Güven, H. (2020). COVID-19 pandemik krizi sürecinde e-ticarette meydana gelen değişimler, Avrasya Sosyal ve Ekonomi Araştırmaları Dergisi (ASEAD), 7(5), 251-268.

Hayta, A. B. (2007). Çalışma ortamı koşullarının işletme verimliliği üzerine etkisi, Ticaret ve Turizm Eğitim Fakültesi Dergisi, (1), 21-41.

Hume, M. (2008). Understanding Core and peripheral service quality in customer repurchase of the performing arts, Managing Service Quality, 18(4), 349-369.

İgeme. (2005). İhracatta Pratik Bilgiler. İgeme.

KARID. (2020). Kargo ve kurye mevzuat1. http://www.karid.org.tr/category/kargo-ve-kurye-mevzuat/ Erişim Tarihi 15 Kasim 2020.

Kayabaşı, A. (2010). Rekabet Gücü Perspektifinde Lojistik Faaliyetlerde Performans Geliştirme. İstanbul: İstanbul Ticaret Odas1.

Keskin, H. (2015). Lojistik el kitabı-küresel aktörlerin lojistik pratikleri. Ankara: Nobel Akademik Yayıncılık Eğitim Danışmanlık Tic. Ltd. Şti.

Keskin, M. H. (2018). Tedarik zinciri yönetimi (geçmişi, değişimi, bugünü, geleceği). 7. bask1. Ankara: Nobel Akademik Yayıncılık Eğitim Danışmanlık Tic. Ltd. Şti.

Kobu, B. (2003). Üretim yönetimi. İstanbul: Avcıol Basım Yayın.

Kotler, P., \& Armstrong, G. (2004). Principles of marketing. New Jersey: Prentice-Hall.

Kut, A. (2017). Karid kargo sektörü durum analizi. http://www.karid.org.tr/kargo-sektoru-durum-analizi-ve-sektorungelecegi/ Erişim Tarihi 15 Kasın 2020.

Küçük, O. (2011). Lojistik ilkeleri yönetimi. Ankara: Seçkin Yayınları.

Lambert, D. M., Stock, J. R., \& Ellram, L. M. (1998). Fundemantals of logistics management. USA: McGraw Hill.

Nebol, E. (2016). Tedarik zinciri ve lojistik yönetimi. Ankara: Nobel Akademik Yayıncılık Eğitim Danışmanlık Tic. Ltd. Şti.

Öge, E., \& Çetin, M. (2020). COVID-19 pandemisi: İnsan kaynakları yönetimi açısından olası etkileri, A. Tutcu, \& S. Gün (Eds) içinde, COVID-19 Süreci ve Örgütsel Yönetim (3-35). Ankara: İksad.

Örücü, E., \& Şeker, C. (2020). Lider-Üye Etkileşiminin Tükenmişlik Üzerindeki Etkisi ve İlişkisi. M. Avc1, \& E. Kara (Eds.) içinde, Örgütsel Davranış Üzerine Güncel Çalışmalar (204-221). İstanbul: Hiperlink Eğitim İletişim Yayıncıllk San. Paz. ve Tic. Ltd. Şti.

Öz, M. (2020). Lojistik faaliyetlerde dış kaynak kullanımı ve pazarlama tabanlı yetenekler üzerine etkisi. Konya: Eğitim Yayınevi.

Özdevecioğlu, M. (2016). Algılanan örgütsel destek ile örgütsel bağlılık arasındaki ilişkilerin belirlenmesine yönelik bir araştırma, Dokuz Eylül Üniversitesi İktisadi İdari Bilimler Fakültesi Dergisi, 2(18), 113-130.

Resmî Gazete. (2021, Ocak). https://www.resmigazete.gov.tr/eskiler/2013/05/20130523-14.htm adresinden alınd1.

Sağlık Bakanlığ1 (2021). COVID Nedir? https://COVID19.saglik.gov.tr/TR-66300/COVID-19-nedir-.html Erişim Tarihi 5 Ocak 2021.

T.C. Cumhurbaşkanlı̆̆ $\quad$ Mevzuat Bilgi Sistemi. (2021). Kargo mevzuatı. hhttps://www.mevzuat.gov.tr/mevzuat?MevzuatNo=21093\&MevzuatTur=7\&MevzuatTertip=5 Erişim Tarihi 5 Ocak 2021.

Taşkın, Ç., \& Emel, G. (2009). İşletme lojistiği-rotalamada sayısal modeller ve çözümlü örnekler. Bursa: Alfa Akademi Basım Yayım Dağıtım Ltd. Şti.

Tekin, İ. Ç. (2020). Pandemi sürecinde değişen tüketici davranışları, Business \& Management Studies: An International Journal, 8(2), 2331-2347.

Thai, V. V., \& Grewal, D. (2005). Selecting the location of distribution centre in logistics operateons: A conceptual framework and case study. Asia Pacific Journal of Marketing and Logistics, 17(3), 3-24.

Ticimax Blog (2021, Ocak). Corona virüsünün e-ticarete etkisi. https://www.ticimax.com/blog/corona-virusunun-eticarete-etkisi Erişim Tarihi 6 Ocak 2021. 
Tuna, A. A., \& Çelen, O. (2020). İşletmelerin insan kaynakları yönetimi uygulamaları üzerinde COVID-19 pandemisinin etkileri, Uluslararası Toplum Araştırmaları Dergisi-International Journal of Society Researches, 16(30), 2710-2759.

Tunçer, P. (2013, Ocak-Mart). Örgütlerde performans değerlendirme ve motivasyon. Sayıştay Dergisi (88), 87-108.

Tutar, E., Tutar, F., \& Yetişen, H. (2009). Türkiye'de lojistik sektörünün gelişmişlik düzeyinin seçilmiş AB ülkeleri (Romanya ve Macaristan) ile karşılaştırmalı bir analizi, 11(17), s. 190-216.

Türk Dil Kurumu Sözlükleri. (2020). https://sozluk.gov.tr/ Erişim Tarihi 15 Kasım 2020

UTIKAD. (2012). Kargo taşımacılığında ilk on. https://www.utikad.org.tr/Detay/Sektor-Haberleri/9938/dunya-kargotasimaciliginda-ilk-10 Erişim Tarihi 15 Aralık 2020.

Yapraklı, Ş. (2006). Kargo taşımacılık hizmetleri pazarlanması ve hizmet kalitesi. İstanbul: Beta Basım Yayın.

Yavan, Ö. (2017). Örgüt psikolojisinde işten ayrılma eğiliminin kavramsal değerlemesi, Kırıkkale Üniversitesi Sosyal Bilimler Dergisi, 7(1), 57-72.

Yıldırım, A., \& Şimşek, H. (2018). Sosyal bilimlerde nitel araştırma yöntemleri. 11. baskı. Ankara: Seçkin Yayıncılık. 


\section{EK:1 Mülakat Soruları}

\section{Kişisel Bilgiler}

- Kaç yaşındasınız?

- Medeni durumunuz nedir?

- Kaçı yıldır lojistik sektöründe çalışmaktasınız?

- Kaç yıldır PTT personelisiniz?

- Eğitim durumunuz nedir?

- $\quad$ (Kişi üniversite mezunu ise) Hangi bölümden mezun oldunuz?

\section{Lojistik Faaliyetlerine İliş̧kin Sorular}

- $\quad$ Pandemi kurallarına ilişkin, görevinizi icra ederken gerekli tedbirler alındı mı? Alındıysa ne gibi tedbirlerdi? Tedbirlere uyuldu mu? Uyulmaması halinde yaptırımları var mıdı?

- Pandemi dolayısıyla kargo, kurye ve posta görevleri haricinde eklenen yeni görevleriniz oldu mu? Olduysa bunlar nelerdir? Çalışma saatlerinizde değişiklik oldu mu?

- Müşterilerin bakış açısının işinize etkisi var mıydı? Etkisi vardıysa bunlar nelerdi?

- Kurumunuzda pozitif vakalara rastlandı $\mathrm{m}$ ? Rastlandıysa bunun kurum içi ilişkilere etkisi nasıl ve ne şekilde oldu? Karantinaya alınan personeller varsa bu durum iş yükünüzü nasıl etkiledi?

\section{3. Çalışanların İşe Yönelik Tutumları}

- COVID-19 pandemi süreci öncesi ve sonrası iş yönelik tutumlarınızı nasıl değerlendirirsiniz?

- Bu süreçte işinizden ayrılmayı ya da sektör değiştirmeyi düşündünüz mü ya da işsiz kalma korkusu yaşadınız mı?

- Pandemi sürecinde yöneticilerin liderlik tutumlarını nasıl değerlendirirsiniz?

- Pandemi sürecinde kurumunuzun size sağladığı desteği nasıl değerlendirirsiniz? 


\section{Extended Summary}

\section{The Effects of COVID-19 on Cargo Workers' Attitudes towards Work: A Case Study of PTT}

During the COVID-19 pandemic, the obligation of consumers to comply with the social distance rule and curfew led to behavioral changes in consumers. Issues such as what the purchased product is, and locale of purchase, form the basis of the changes. During the pandemic, the demand for basic needs has increased and online shopping has gained prominence. Food, health, and hygiene products have come to the fore, while the change in consumer attitude has developed in the direction of healthy life, demand for online shopping, digitalization, and prosocial consumption (Çakıroğlu, Pirtini, \& Çengel, 2019: 86-96). Regarding the increasing demand, most cargo companies have been inefficient in the field of logistics. As a result of changing consumer behavior due to the pandemic, some sectors have grown while some sectors have shrunk. Researches on these sectors show that people's adaptation to the innovations brought by the pandemic and their orientation to new products and services to meet their changing needs can permanently change some of their attitudes (Tekin, 2020: 2344-2346). The COVID-19 pandemic has changed people's consumption habits significantly. One of the most important effects of the period is that it has evolved social and commercial life towards digitalization. With the growth in e-commerce, one the one hand the demand for some products increased, on the other the demand for some products tended to decrease. For example, the demand for health and personal care products has increased, while the demand for clothing and accessory product groups has decreased (Güven, 2020: 260-265).

While the pandemic negatively affected all sectors, it had a contrary effect in the ecommerce world, and a leap in e-commerce was experienced. Reasons such as quarantine and prohibitions, the danger of going out on the streets, and avoidance of physical contact have negatively affected physical trade. Even though physical stores are negatively affected, it is inevitable that people's needs will continue. Although conditions change, human need continues at different scales (Ticimax Blog, 2021). With the increase in e-commerce, the workload of cargo companies has increased, and cargo companies have often been inadequate in the presence of the fact. In line with all this information, this study attempted to determine the effects of the new coronavirus pandemic that emerged in 2020 in the field of cargo distribution in the logistics sector and to observe whether there is a change in the job satisfaction levels of employees. While the COVID-19 pandemic affects our lives in many ways, both positively and negatively, it is inevitable that cargo distribution, which takes an important place among logistics activities, will be greatly affected by this circumstance. In our study, we tried to measure the change in the attitudes of 22 delivery person working in PTT cargo delivery operating in Bartın. 22 PTT delivery person working in the central district of Bartın were interviewed using a semi-structured interview technique. As a result of the research, it was revealed that there was an increase of $26 \%$ in cargo deliveries compared to the period before the pandemic, and the increased workload negatively affected the motivation and job satisfaction of the employees.

Extra works added due to the pandemic increased the workload and caused a decrease in the level of motivation for work. In this case, the institution should take actions to increase motivation. Increased workload should be reflected in the wages. Most of the employees think that the viewpoint of the customers towards the employees has been negative during the pandemic period, has a very negative effect on the work motivation of the employees. During the pandemic, the working conditions of cargo workers have become more severe than before. Cargo employees worked full-time during this period, even worked during the curfew, and did not start working alternately. Most of the time, they could not even have time for lunch. The perception of cargo employees should change to eliminate the negative effect of customers' attitude towards cargo employees. To change the negative perception of cargo employees in 
customers, the institution should inform the public about how difficult and important tasks cargo employees have undertaken and broadcast public advertisements. As can be seen in the research, all the employees think that the workload has increased, and $81 \%$ of them express that there is an increase in both overtime and workload.

Increase in workload causes stress, and the stress causes inefficiency in employees. Therefore, managers and leaders have important roles in reducing the stress environment. In addition, as mentioned in the findings section, the use of technological developments both facilitates the work of cargo employees and protects their health during sensitive periods such as pandemics. However, it should not be forgotten that technological developments work in integrity with integrated systems. For example, even though cargo employees use hand terminals that facilitate their work and protect their health, the lack of infrastructure prevents the usage of these tools effectively, as the hand terminals need signal to operate. With the development of telecommunication infrastructure, the use of hand terminals will become possible in the villages, so efficiency will increase more. 
Optimum Journal of Economics and Management Sciences, Vo1. 8, No. 2- https://dergipark.org.tr/tr/pub/optimum Dönmez Topçuoğlu and Genç - The Effects of COVID-19 on Cargo Workers' Attitudes Towards Work: A Case Study of PTT 